\title{
Entrepreneurship Education Learning Model in Vocational Secondary School
}

\author{
Sarwa \\ Civil Engineering Dept. \\ Engineering Faculty, Medan State University \\ Medan, Indonesia \\ ewo.sarwa@yahoo.co.id
}

M. S. Barliana

Architecture Engineering Education Dept.

Faculty of Technology and Vocational Education, UPI

Bandung, Indonesia

aombarli@upi.edu

\author{
A. Djohar \\ Mechanical Engineering Education Dept. \\ Faculty of Technology and Vocational Education, UPI \\ Bandung, Indonesia \\ adjohar@gmail.com \\ Suryana \\ Management Dept. \\ Faculty of Economic and Business Education, UPI \\ Bandung, Indonesia \\ suryana_upi@yahoo.com
}

\begin{abstract}
The research objective was to develop a learning model of Entrepreneurship Education (EE) in vocational secondary school (SMK). The development of a learning model was designed to Experiential Learning Theory (ELT), which is aligned with best practices in SMK. The research method used Research and Development ( $R$ \& $D$ ) model consisting of three stages: preliminary study, model development, and classroom experiment. The results of a preliminary study of six SMK in Medan, Binjai and Deli Serdang showed that there were learning materials on theoretical entrepreneurship, learning methods with lectures and discussions, and learning evaluation which was conducted using a written test. The design of teaching materials "Craft and Entrepreneurship" was incompatible with the competency of vocational students. EE learning model that is suitable for vocational students is practical entrepreneurship of technopreneur, Experiential Learning Method, portfolio and observation base evaluation.
\end{abstract}

Keywords-Entrepreneurship Education, Experiential Learning, Technopreneur

\section{INTRODUCTION}

Currently the number of entrepreneurs in Indonesia amounted to $0.24 \%$ of the total population, but to be an economically advanced nation, the number of entrepreneurs should be at least 2\%. (Source: finance.detik.com, June 2013). When associated with businesses that educational background in vocational schools (SMK), which is only $1 \%$, Djoko Sutrisno hope there are at least $10 \%$ of graduates that can be self-employed (source: www.suaramerdeka.com, November 2010). Djoko's statement is an evaluation of the success of the SMK, which has a mission in preparing for entrepreneurial skills. According to the Central Bureau of Statistics (BPS), the total unemployment is about $7.21 \%$ or about 1 million people which were graduates of SMK (BPS, 2014). This figure is still relatively high referring to the main mission of SMK graduates who is able to work. Referring to the number of unemployed and the small number of vocational graduates who are self- employed, it is necessary to strengthen learning EE for SMK students.

Several government programs have been done much to foster the entrepreneurial community in an effort to increase the number of new entrepreneurs through the Ministry of Manpower and Transmigration, Ministry of Cooperatives and SMEs, or the Ministry of Education and Culture. Various programs have been implemented by the government in the form of coaching, training, provision of capital, or the movement of entrepreneurship campaigns. One of program efforts EE through Kemendikbud is the enactment of an entrepreneurial curriculum in SMK.

EE in SMK curriculum has been implemented in 2006 as a change or development of Business Management subjects. Last EE curriculum development in 2013 has been designated by the name of Craft and Entrepreneurship subjects. Provision of Craft and Entrepreneurship subjects in the curriculum in 2013 is not only required in SMK but for Senior High School (SMA), and Madrasah Aliyah (MA) which aims to foster the spirit of entrepreneurship from an early age (Kompas, February 27,2013 , p. 12). In the curriculum of SMK, the graduates are prepared for working, continuing further studies and being entrepreneurs. Based on the description of SMK graduates employment opportunities, there are several possible processes to be working or self-employment. The first possibility vocational school graduates go to work and continue until the end of their productive age. The second possibility, worked out while saving for later quit work continues to plunge entrepreneurship. The third possibility, after several years of work, workers start businesses in the part-time while still working, and eventually will be in full time to focus on running the business. The fourth possibility is directly entrepreneurship after graduation.

Based on the evaluation of the successful implementation of EE in SMK, many factors that determine it, one very 
important factor is the learning model applied Teachers. For this reason the author in seeking improvements EE in SMK.

\section{A. Entrepreneurship Learning Model}

The learning model is a form of a learning scenario typically presented by the teacher from the beginning to the end of learning. In another sense, the learning model is the packaging or the framework of the implementation of an approach, methods, and techniques of learning. With regard to the learning model, Bruce Joyce and Marsha Weil (translation, 2009) classifies four groups of learning model, namely: (1) social interaction models; (2) model of information processing; (3) the model of personal-humanistic; and (4) a model system behavior. However, the use of the term learning model is often identified with learning strategies. In addition to, the learning process is also known as terms of instructional design. If learning strategy relates the general pattern and the general procedures of learning activities, instructional design is more points to ways of planning a particular learning environment system after a particular set of learning strategies. The design sets blueprint about the learning that will be developed from material required and the stages of implementation, and completion criteria, ranging from the initial stage to the final stage, after the set learning design is developed. Actual teaching models could also be considered as models of learning (Joyce, BR, Weil, M., \& Calhoun, E., 2009. p. 7). According to Paul Eggen and Don Kauchak (2012, p. 8), a model of teaching is a kind of blueprint for teaching. As the blueprint provides structure and direction to the engineers on the job building, the model provides guidance for teachers. From these two statements, it can be obtained two important points about learning model: the learning model cannot be distinguished from the teaching model, and the model of teaching is according to the scenario for teachers.

Operationally learning model will be lowered as the approaches, strategies, methods, techniques and tactics and even learning. The cycles into a coherent whole they form what is called a learning model.

Learning approach can be interpreted as a starting point of our view of the learning process, which refers to the view of the occurrence of a process that is still very common, in which embodies, inspires, strengthens, and underlie learning methods with specific theoretical coverage. Based on its approach, there are two types of learning approaches, namely: 1) learningoriented approaches or centered on students (student centered approach) and 2) learning-oriented approaches or centered on the teacher (teacher centered approach)

According to Kemp (Wina Senjaya, 2008), it is suggested that the learning strategy is a learning activity that must be done so that the teacher and student learning objectives can be achieved effectively and efficiently. Furthermore, quoting from David J. R, Wina Senjaya (2008) states that learning strategies contain in the meaning of the planning. The strategy is still conceptual about the decisions to be taken in an implementation of learning.

Based on its strategy, learning can be grouped into two parts as well, namely: (1) exposition-discovery learning and (2) group-individual learning (Rowntree in Wina Senjaya, 2008). Based on the manner of presentation and way of processing, learning strategies can be distinguished between inductive learning strategies and deductive learning strategies. Learning strategies are still conceptual in nature and are used to implement a variety of specific teaching methods. In other words, the strategy is "a plan of operation achieving something" while the method is "a way in achieving something" (Wina Senjaya, 2008).

\section{B. Learning methods}

Thus, the method of learning here can be interpreted as the means used to implement the plan that has been prepared in the form of real and practical activities to achieve learning objectives. There are several methods that can be used to implement learning strategies, including: (1) lectures; (2) demonstration; (3) discussion; (4) simulation; (5) laboratory; (6) field experience; (7) brainstorming; (8) debate, (9) symposia.

\section{Learning Techniques}

Learning methods are translated into learning techniques and tactics. Thus, learning techniques can be defined as a way one does in implementing a specific method. For example, using a lecture in a class with a relatively large number of students who need a different technique, which is certainly technically will vary with use classroom lecture method in which a limited number of students. Similarly, the use of the method of discussion, it is necessary to use different techniques in the classroom where students classified as active with students classified as passive classes. In this case, the teacher can be alternated technique though applying the same method.

\section{Entrepreneurship and Entrepreneurship Education}

Entrepreneurship and Entrepreneurship Education (EE) have a fundamental difference in the substance of the study material. Entrepreneurship is a massive attitude or behavior that encourages someone to build a business. Entrepreneurship is associated with four key capabilities including to develop, manage, take risks, and make a profit. It is the capacity and willingness to develop, organize and manage a business venture along with any of its risks in order to make a profit. The most obvious example of entrepreneurship is starting new businesses. Another definition of EE is real action that has orientation on the product or innovation through the management of resources in increasing productivity, creating of new commodities, new ways of producing, creating new markets or new materials (Ruskovara et al., 2011, p. 23). The definition EE associated with the world of school (formal education) is a didactic disciplines as a realization of the educational process that teaches learners (students) about how to cope with the complex economic reality. As presented by Wawer et al, "entrepreneurship is a discipline of didactics and realization of the educational process in order to teach the course of participants and students ways of coping with existence in a complex economic reality" (2010). From this definition, it is indicated that the debriefing of EE can be done through the process of formal education or learning. Another definition EE, according Ruskovara et al. (2011, p. 4) is an effort to introduce entrepreneurship as a career option, to give encouragement about how entrepreneurship is becoming a major feature of the teaching and learning activities. Complete Ruskovara et al stated: "Entrepreneurship education introduces entrepreneurship as a career choice, it supports the entrepreneurial way of seeing and doing things and it 
characterizes a way of teaching and learning". It means that EE is encouraging entrepreneurial student or students in class activities (learning).

$\mathrm{EE}$, when associated with education for young people (students), refers to the opinion delivered by Ruskovaara et al (2010, p. 23). that "Entrepreneurship education for younger students has been suggested to concern more about learning the spirit and ways of doing and seeing than about business activity. The aim is that students could take more responsibility for Themselves and their learning ". It means that EE student is about spirit (spirit), how to do and how to look at the values of entrepreneurship rather than on the business activity or business. The purpose and impact of learning EE emphasise on the character formation of students that has responsibility for themselves and ultimately improve their learning spirit.

Based on some definitions of EE, there are key points of the definitions:

1. EE is the process of providing capability in the form of capacity: reading opportunities, develop new business, manage or run a business, and seek (orientation) profit.

2. $\mathrm{EE}$ is the discipline of learning (didactic) which equips students to be able to face the world economic competition.

3. EE is an effort to provide options and support entrepreneurship as a career option.

4. EE for all young people (students) is about the cultivation of the spirit and values to encourage the spirit of learning.

\section{Entrepreneurship Education and Business Education}

$\mathrm{EE}$ is different from the concept of business education $(\mathrm{H}$. Lobler 2006, p. 24). Lobler compares the differences about the character of Education Business and Entrepreneurship Education from 1) material, 2) approach, 3) teachers, 4) learning resources, 5) provision of teachers, 6) provision of student, 7) learning environment.

\section{E. Entrepreneurship Education Learning}

TABLE 1. DifFERENCES IN EDUCATION BUSINESS AND EE*)

\begin{tabular}{|c|c|c|}
\hline & Business Education & Entrepreneurship Education \\
\hline Focus & Sciences & Process \\
\hline Learning & Transfer of science & Support of learning process \\
\hline Purpose & Business science & $\begin{array}{l}\text { Learning for life, autonomy, and } \\
\text { the ability to manage } \\
\text { independently }\end{array}$ \\
\hline $\begin{array}{l}\text { Provisions for } \\
\text { teacher }\end{array}$ & transmitter & Assistants students (learners) \\
\hline $\begin{array}{l}\text { Provisions for } \\
\text { student }\end{array}$ & $\begin{array}{l}\text { Listener /participants as } \\
\text { passive audience }\end{array}$ & active as a producer \\
\hline Learning Source & Teacher and books & Various sources \\
\hline $\begin{array}{l}\text { Needs } \\
\text { information } \\
\text { acquisition }\end{array}$ & Teachers and curriculum & $\begin{array}{l}\text { Demand and the needs of } \\
\text { students }\end{array}$ \\
\hline $\begin{array}{l}\text { Classroom } \\
\text { direction }\end{array}$ & Teacher & Student \\
\hline Interaction & Teacher-Student & $\begin{array}{l}\text { Students, Teachers are no } \\
\text { exception }\end{array}$ \\
\hline Activity & Listening, reading & Talking, listening, and doing \\
\hline
\end{tabular}

${ }^{*}$ Modified from Lobler H. (2006), p. 24
Constructivism approach is more suitable to be applied in teaching $\mathrm{EE}$ in the achievement of learning outcomes that can be formulated by the learner. One of the most important characteristics of learning based constructivism Entrepreneurship Education is in the process of achievement of student-centered learning (SCL: student learning center), meaning that the material is not transferred by the teacher but will be obtained from the student's own experience $(\mathrm{H}$. Lobler, 2006).

\section{F. Characteristic of Entreprenial Learning}

According to the FG Alberti et al. (2005), are six learning characteristics, namely:

1. The purpose of education: how is the aim and learning process developed?.

2. Learning materials: Which sources are developed and by whom are set?

3. Teacher: how is the provisions on the duties and role of the teacher?

4. Students (learners): how is the regulation of students? Who organized the learning process, the teacher or student?

5. The evaluation system: how does the evaluation system do?

6. Aspects of pedagogy: how is 'teaching', 'knowledge' and 'information' designed? How do the interaction become the main activity in the learning process? How is the transaction of learning resources delivered as information?

\section{G. The principles of Experience Based Learning}

According to AEE (Association for Experiential Education, 2011, para 4), the principles of the experiencebased learning is as follows:

1. The learning experience is supported by a carefully selected reflection, critical analysis and synthesis.

2. Structured learning experience for students is to take the initiative, make decisions and take responsibility for the results.

3. Students are actively engaged in asking questions, investigate, experiment, solve problems, responsibility, being creative and constructing meaning.

4. Students are involved in intellectual, emotional, social, and/or physical activities.

5. Students are involved in generating the perception in authentic learning tasks.

6. The result of learning is individual as the basis for the formation of capital as a learning experience for the future.

7. Development and maintenance of relationships focus on ourselves, others and the environment.

8. Teachers and students can achieve success, failure, risks and uncertainties, as a result of our experience cannot predict accurately.

9. Students and teachers have equal opportunities in exploring and learning about positive values to their own. 
10. The main role of the instructor in setting experience: choose a problem, restricting the limits, student support, ensuring the physical and emotional safety, and facilitate the learning process.

11. The instructor encourages spontaneous opportunities in learning.

12. Instructor seeks to sensitize students bias, assessment and pre-conception, and how they affect the students.

13. The design of the learning experience should be able to allow students to learn from natural consequences, mistakes and successes.

\section{RESEARCH METHODS}

The research design was Research and Development ( $R$ \& D) of Borg and Gall (1983).

In simple terms, all stages of the research plan is divided into 3 stages include: 1) a preliminary study, 2) the development of models, and 3) test the model. In detail, the procedures or operationally stages of research that has been carried out as follows.

\section{A. Preliminary Study}

Preliminary research has been done through literature studies and field studies. Literature studies have been conducted through review of the literature in the form of journals articles, textbooks and government policy.

The process of literature review aims to explore the concepts and theories related to the research topics that can be extracted from the source of government policies relating to the legal basis and guide the implementation techniques EE learning, theoretical concepts that have been tested and the results of previous research. The process of literature study has been carried out since the set until the final completion of the research topic of research reports.

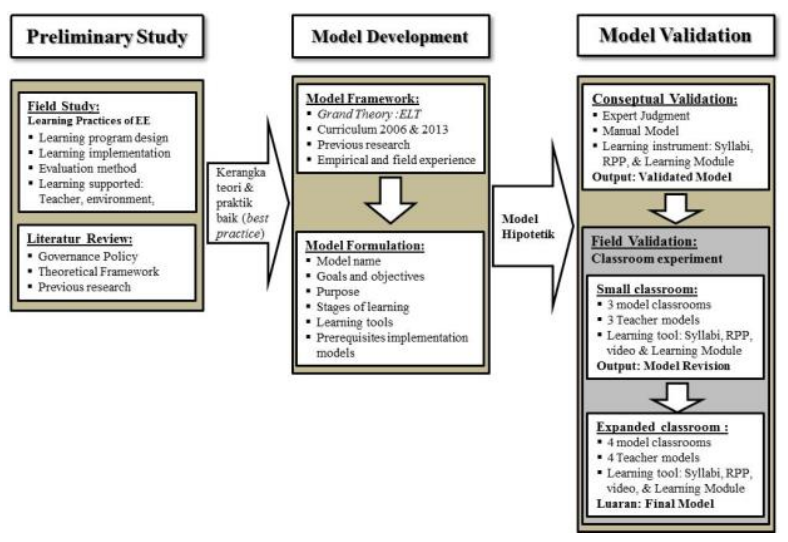

Fig. 1. Stages of R \& D Process

The literature review is to get the results of previous studies that are relevant to the research topic. In accordance with the definition of Creswell, "a literature review is a written summary of the journal article, books, and other documents that describe the past and current state of information on the topic of your research study" (Creswell, JW, 2012, p. 80), the results of the study of literature is a summary and mapping of the objectives, methods and results of previous studies. The benefit from the study of literature is to avoid duplication, and the position of our research is useful to construct a theory in the development of new research.

\section{B. Literature Review}

According to the the implementation the 2013 curriculum of SMK, development of "Competency Group" and the 2013 Curriculum need to be guided. The changes of "Competency Group" which requires attention is about the change of nomenclature groups of competence in vocational skills. In accordance with the decision of the Director General of Secondary Education Ministry of Education and Culture there are 9 Vocational Fields (nine) with 128 Vocational. EE in curricular subjects outlined in Craft and Entrepreneurship as a compulsory subject in the curriculum of 2013

In addition to document analysis literature studies through government policy, a field study was conducted in six SMK and was done through technical document review, interviews, and observations. Based on the results of a preliminary study of data acquisition, it is acquired the formulation and development framework for vocational learning model EE.

\section{Model Development}

Based on the results of the preliminary study, researchers developed a model that accommodated the best experience, policy guidance and support of the theory. The next step is to build a model of early learning EE design. The initial product or hypothetical model includes learning standards EE equipped with operational tools of learning: guidelines for the implementation of the model, syllabus and learning design, and learning modules. Model validation process was performed by sexpert judgment as the conceptual model of due diligence and operational effectiveness test conducted through classrooom experiments (class model).

\section{RESULTS AND DISCUSSION}

Entrepreneurship learning practices in class XII SMK were explored by questionnaires, interviews and classroom Implementation of Curriculum 2013.

TABle 2. QuAlity of LEARning PROGRAM DESIGN (RPP)

\begin{tabular}{|c|c|}
\hline No. Cor & Description \\
\hline 1. Iden & $\begin{array}{l}\text { Already equipped with: name of subjects, number of } \\
\text { hours of study, time clock, the target class, teacher } \\
\text { name, meeting time. Specifically RPP were } \\
\text { developed for all classes regardless Skill } \\
\text { Competency. }\end{array}$ \\
\hline $\begin{array}{l}\text { 2. Statement of } \\
\text { competence }\end{array}$ & $\begin{array}{l}\text { Already formulated SK (competency standards), KD } \\
\text { (basic competencies), learning objectives, and } \\
\text { indicators of learning achievement. }\end{array}$ \\
\hline $\begin{array}{l}\text { 3. Lea } \\
\text { mat }\end{array}$ & $\begin{array}{l}\text { The subjects include: analysis of business } \\
\text { opportunities, business plan, business management, } \\
\text { and analysis of business risk. The learning material } \\
\text { refers to the syllabus Curriculum } 2006 \text { (theoretical) }\end{array}$ \\
\hline $\begin{array}{l}\text { 4. Learning } \\
\text { Method }\end{array}$ & $\begin{array}{l}\text { Learning methods are most commonly used: } \\
\text { lectures, question and answer, and discussion }\end{array}$ \\
\hline $\begin{array}{l}\text { 5. Evaluation } \\
\text { method }\end{array}$ & $\begin{array}{l}\text { Evaluation techniques were used: a written test } \\
\text { (essay or multiple choice) }\end{array}$ \\
\hline
\end{tabular}


Observation results of learning practices EE obtained are summarized in Table 2 and Table 3. Table 2 illustrates the quality of the EE learning design is written in the $R P P$ (Learning Program Design). Table 3 presents the results of classroom observation concerning the implementation of learning activities

To complete the data in the development of a more implementable models, the study of the readiness of the implementation of Curriculum 2013, especially about subjects craft and Entrepreneurship. Based on the results of document review, observation of teacher training aims, and an interview with the principal, the authors derive a conclusion and a note as follows:

1. EE teaching materials were taught the craft skills should be taught about entrepreneurship.

2. Teaching materials are equated with SMA.
3. The material provided does not correspond to the productive skills of vocational students.

4. Teachers have difficulty in implementing good craft materials about the technology, craft, processing and cultivation.

5. The scientific approach is not fully applicable in the classroom

6. Vocational students have mastered the productive competence in the form of vocational skills.

7. Material "productive" should have been embedded in the subjects of Entrepreneurship.

Framework and Characteristics of EE Model

Based on the results of preliminary studies, the framework EE suitable learning model developed for the vocational fields of Technology and Engineering displayed frame as presented in Table 3.

TABLE 3. TERMS OF REFERENCE DEVELOPMENT MODEL

\begin{tabular}{|c|c|c|c|}
\hline \multirow{2}{*}{ Description } & \multicolumn{2}{|c|}{ Result } & \multirow{2}{*}{ Proposed Development } \\
\hline & Curriculum 2006 & Curriculum 2013 & \\
\hline Subjects name & Entrepreneurship & Craft and Entrepreneurship & Entrepreneurship \\
\hline Learning goal & $\begin{array}{l}\text { Building the character (attitude), } \\
\text { implement and execute entrepreneurial } \\
\text { science }\end{array}$ & $\begin{array}{l}\text { Making a products, building an } \\
\text { autonomy character, creative, } \\
\text { responsibility }\end{array}$ & $\begin{array}{l}\text { Starting a small business field of technology } \\
\text { (technopreneur) }\end{array}$ \\
\hline $\begin{array}{l}\text { Focus of learning } \\
\text { material }\end{array}$ & Theoretical entrepreneurship & Craft & Practical entrepreneurship \\
\hline Students target & Specific for $S M K$ & For $S M A$ and $S M K$ & For $S M K$ "Technology and Engineering" \\
\hline Principal matter & $\begin{array}{l}\text { - } \text { attitudes and behavior of } \\
\text { - } \text { entrepreneurs } \\
\text { - } \text { leadership and behaviors prestatif } \\
\text { - } \text { running a business }\end{array}$ & $\begin{array}{l}\text { - Crafts } \\
\text { - Cultivation } \\
\text { - Engineering } \\
\text { - Processing }\end{array}$ & $\begin{array}{l}\text { - Technopreneur: } \\
\text { - know the technological business world } \\
\text { - analysis of business opportunities } \\
\text { - prepare a business plan } \\
\text { - run a small business field of technology }\end{array}$ \\
\hline Competency standard & $\begin{array}{l}\text { - } \text { entrepreneurial attitudes } \\
\text { - leadership } \\
\text { - } \text { planning a small or micro } \\
\text { enterprises } \\
\text { - managing a small or micro } \\
\text { enterprises }\end{array}$ & $\begin{array}{l}\text { Running a business } \bullet \text { Determined per- } \\
\text { class level; SMK in level } 7 \text { (class X and } \\
\text { XI), level } 8 \text { (class XII) }\end{array}$ & $\begin{array}{l}\text { - Understanding the the technological } \\
\text { business world } \\
\text { - Applying business opportunities } \\
\text { - Planning of business } \\
\text { - Start-up a new business }\end{array}$ \\
\hline Learning Method & not defined & $\begin{array}{l}\text { Scientific approach } \\
\text { Method: project base, discovery learning }\end{array}$ & $\begin{array}{l}\text { Scientific approach } \\
\text { Model : Experiential Learning }\end{array}$ \\
\hline Evaluation Method & not defined & Authentic assessment & $\begin{array}{l}\text { Observation and } \\
\text { Portfolio }\end{array}$ \\
\hline
\end{tabular}


Based on the model framework as defined in Table 4, the formulation of specifications for vocational learning of EE Model is presented in Table 4. The spesification of learning model is adaptation of Experiential Learning Theory (Kolb, 2001)

TABLE 4. SPECIFICATIONS OF ENTREPRENEURSHIP LEARNING MODEL IN SMK

\begin{tabular}{|c|c|}
\hline Component & Description \\
\hline Model Name & $\begin{array}{l}\text { Experiential-based Entrepreneurship Education for } \\
\text { Vocational Secondary School (SMK) }\end{array}$ \\
\hline Objective & $\begin{array}{l}\text { EE learning development for vocational students in } \\
\text { accordance with vocational skills }\end{array}$ \\
\hline Purpose & $\begin{array}{l}\text { Increasing the effectiveness of EE learning in } \\
\text { Vocational Secondary School (SMK) }\end{array}$ \\
\hline Grand theory & Experiential Learning Theory (ELT) \\
\hline \multicolumn{2}{|c|}{ Characteristic of Learning Model : } \\
\hline - syntac & $\begin{array}{l}\text { Reflective observation } \\
\text { o inspiring experiences exploration } \\
\text { o abstract conceptualization } \\
\text { o simulative experiment }\end{array}$ \\
\hline $\begin{array}{l}\text { - Models supporting } \\
\text { instruments }\end{array}$ & $\begin{array}{l}\text { the manual model, the syllabus, lesson plans, } \\
\text { learning modules }\end{array}$ \\
\hline - Evaluation model & Kirkpatrick Model \\
\hline Indicator & \\
\hline - Learning design & the feasibility of supporting instruments models \\
\hline $\begin{array}{l}\text { - The effectiveness of } \\
\text { the model } \\
\text { implementation }\end{array}$ & sequences, time-frame, replication dan transferable \\
\hline - Result & accepted by teachers and students \\
\hline
\end{tabular}

\section{CONCLUSIONS AND RECOMMENDATIONS}

\section{A. Conclusion}

Based on the results of preliminary studies, at the end of this stage it can be summarized as follows:

The principles of EE teaching materials in class XII: setting up the businesses, risks management, business management, and evaluate business.

EE teaching materials are designed for all classes regardless Vocational Competency.

1. The learning method applied: lecture, question and answer, and discussion.

2. Evaluation method was done by written tests and oral tests.

3. Characteristics of EE Curriculum 2013 is incompatible with the character of competency skills of vocational students.

4. EE subjects in the curriculum in 2013 contains about craft, not about entrepreneurship.

\section{B. Recommendation}

Based on the analysis of the findings and issues obtained from literature and field studies development suggestions based Entrepreneurship Education Learning Model ELT is as follows:

1. The development of EE teaching materials should be aligned with the vocational skills of students.

2. The method developed is suitable learning Class Simulations.

3. Presence Production Unit $(U P)$ should be optimal in supporting entrepreneurship learning.
4. Development of learning tools in Learning Modules should be designed to align the ELT approach.

5. Appropriate teacher to teach EE is Economics educational background and have experience or interest in the field of Technology and Engineering

\section{ACKNOWLEDGMENT}

This research was funded by research grants of Fundamental Scheme of Indonesia Higher Education (Dikti) Year 2014-2105.

\section{BIBLIOGRAPHY}

[1] Detik.com. (2013). RI Butuh 4,18 Juta Wirausaha Baru, Cak Imin Latih Pengangguran SD dan Sarjana. Tersedia: http://finance.detik.com / /read/2013/06/01/161303 /2262232/4/ributuh-418-juta-wirausaha-baru-cak-imin-latih-pengangguran-sd-dansarjana. 01 Juni 2013. Diunduh: 19 Juni 2013

[2] Suara Merdeka On-line. (2010). Benahi Kualitas dan Fokus Wirausaha, tersedia: http://www.suaramer-deka. com/v2/index.php/read/ cetak/2010/11/24/130920/Benahi-Kualitasdan-Fokus-Wirausaha. 24 November 2010. Diunduh: 19 Juni 2013

[3] BPS. (2014). Berita Resmi Biro Pusat Statistik No. 38/05/Th. XVII, 5 Mei 2014. Jakarta : Biro Pusat Statistik

[4] Kompas. (2013). Wajib Pendidikan Kewirausahaan di SMK. Jakarta, Kompas 27 Februari 2013, hal. 12

[5] Bruce Joyce dan Marsha Weil. (2009). Model of Teaching Ed. 8th (terjemahan). Jakarta : Pustaka Pelajar.

[6] Eggen, P. D. \& Kauchak, D. P., (2012). Strategi dan Model Pembelajaran (translation). Jakarta : Indeks

[7] Wina Senjaya. (2008). Strategi Pembelajaran; Berorientasi Standar Proses Pendidikan. Jakarta: Kencana Prenada Media Group.

[8] Ruskovaara, E., Pihkala, T., Rytkölä, T., \& Seikkula-Leino, J. (2010). Studying Teachers' Teaching Methods and Working Approaches in Entrepreneurship Education. In ESU Conference, Tartu, August 2010. (pp. 22-28).

[9] Wawer M, Miłosz M, Muryjas P, Rzemieniak M. (2010). Business Simulation Games in Forming of Students' Entrepreneurship. International Journal of Euro-Mediterranean Studies, 01/2010; 3(1):49-71.

[10] Löbler, H. (2006). Learning entrepreneurship from a constructivist perspective. Technology Analysis \& Strategic Management, 18(1), 19-38.

[11] F. G. Alberti, S. Sciascia \& A. Poli. 2005. The Domain of Entrepreneurship Education: Key Issues. International Journal of Entrepreneurship Education, 2, 2005, pp. 453-482

[12] AEE. Experiential Learning. (2011) Northern Illinois University, Faculty Development and Instructional Design Center. Tersedia: http://www.niu.edu/facdev/

resources/guide/strategies/experiential_learning.pdf. Downloaded: June 2nd 2013.

[13] Borg, W.R. and Gall, M.D. (1983). Educational Research: An Introduction. London: Longman, Inc.

[14] Creswell, J. W. (2012). Educational Research: Planning, Conducting, and Evaluating Quantitative and Qualitative Research, 4th Edition. Pearson

[15] Kolb, D. A., Boyatzis, R. E., \& Mainemelis, C. (2001). Experiential learning theory: Previous research and new directions. Perspectives on thinking, learning, and cognitive styles, 1, 227-247. 